\title{
鼻副鼻腔癌の転移と分化度の関係
}

\author{
香川医科大学耳鼻咽喉科学教室（主任：酒井俊一教授） \\ 宮口衛, 酒 井 俊一
}

\section{A CORRELATION BETWEEN METASTASIS AND HISTOPATHOLOGICAL DIFFERENTIATION IN PATIENTS WITH CARCINOMA OF THE NASAL CAVITY AND PARANASAL SINUSES}

\author{
MAMORU MIYAGUCHI, M.D. and SHUN-ICHI SAKAI, M.D.
}

\section{Department of Otorhinolaryngology, Kagawa Medical School, Kagawa}

The aim of this retrospective study was to investigate a correlation between histopathological differentiation and metastasis in patients with carcinoma of the nasal cavity and paranasal sinuses to improve the survival.

Between 1984 and 1992, 52 cases of sino-nasal malignant tumors were treated at Kagawa Medical School Hospital. Squamous cell carcinoma was evaluated in 29 patients and undifferentiated carcinoma in five patients.

Treatment in most cases consisted of radiotherapy, $50 \mathrm{~Gy} / 25 \mathrm{fr} / 5$ weeks, continuous intraarterial infusion of 5-FU $2000 \mathrm{mg} / 4$ weeks, and an extensive Denker's operation 2-3 weeks after the completion of radiotherapy. The 5-year survival rate was $53 \%$, and the local control rate was $82 \%$. Patients died of local failure (six), distant metastases (six), lymph node metastases (one) and other causes (three).

Twenty-eight patients with local control were classified into G1-2 (well- and moderately differentiated) and G3-4 (poorly-differentiated and undifferentiated) groups. Lymph node metastasis was unrelated to the degree of differentiation, but distant metastasis was significantly correlat. ed to the degree of differentiation ( $P=0.014$ ). The 5-year survival rates in lymph node metastasis $(\mathrm{n}=7)$, non-lymph node metastasis $(\mathrm{n}=21)$, distant metastasis $(\mathrm{n}=7)$, non-distant metastasis $(\mathrm{n}=$ $21)$, and the G1-2 ( $n=17)$ group and the G3-4 group ( $n=11)$ with local control were $57 \%, 63 \%, 14 \%$, $78 \%(P=0.002), 72 \%$ and $44 \%(P=0.0384)$, respectively. The results of combination therapy were poor in patients with poorly-differentiated or undifferentiated carcinoma because of distant metastasis, and adjuvant chemotherapy may be necessary in such patients to prevent distant metastasis.

Key words : 上顎癌, 鼻副鼻腔癌, 遠隔転移, リンパ節転移

A $97-2097-30311$

\section{Iはし゚めに}

鼻副鼻腔癌の治療法住, 放射線単独, 手術単独, 両 者の併用,さらに化学療法の併用と多岐にわたる。近 年本邦では，集学治療として三者併用療法（放射線照 射, 化学療法, 手術) が主流となってきている。しか
し，三者の併用法や放射線量は施設によって異なって いる. 各施設の放射線量と 5 年生存率は, 北里大学で は 16Gy で T3 以下て7 $79 \%, T 4$ で約30\%" ${ }^{11}$, 久留米大学 では $20 \mathrm{~Gy}$ で $62 \%$ ( 3 年粗生存率 $)^{2)}$, 自治医科大学では $30 \mathrm{~Gy}$ 以下で T3 では $88 \%$, T4 では $64 \%{ }^{3)}$, 東京慈恵会 
表 1 局所制御不能であった 6 例

\begin{tabular}{|c|c|c|c|c|c|c|c|c|c|}
\hline \multicolumn{3}{|c|}{ 症 例 } & 原 発 & $\mathrm{T}$ & $\mathrm{N}$ & M & 分化度 & 治 & 再発(月) \\
\hline 1. & 61 & 女 & 鼻腔 & $\mathrm{X}$ & 0 & 0 & 低 & $70 \mathrm{~Gy}, 5 \mathrm{FU}(2000 \mathrm{mg})$, 鼻側切開術 & 10 \\
\hline 2 . & 61 & 男 & 鼻腔 & $\mathrm{X}$ & $2 \mathrm{c}$ & 0 & 低 & $52 \mathrm{~Gy}, \quad \mathrm{CBDCA}(200 \mathrm{mg})$ & 根治不能 \\
\hline 3. & 76 & 男 & 上頱洞 & 3 & 0 & 0 & 中 & $50 \mathrm{~Gy}, 5 \mathrm{FU}(2000 \mathrm{mg})$, デンケル手術 & 15 \\
\hline 4. & 80 & 女 & 上顎洞 & 4 & 0 & 0 & 中 & $60 \mathrm{~Gy}$ & 6 \\
\hline 5. & 57 & 男 & 上顎洞 & 4 & $2 c$ & 0 & 中 & $50 \mathrm{~Gy}, 5 \mathrm{FU}(1800 \mathrm{mg})$ & 根治不能 \\
\hline 6. & 60 & 男 & 上靧洞 & 3 & 0 & 0 & 高 & $50 \mathrm{~Gy}, 5 \mathrm{FU}$ (2000mg), デンケル手術 & 2 \\
\hline
\end{tabular}

医科大学では $40 \mathrm{~Gy}$ で $62 \%{ }^{4)}$, 大阪大学では $50 \mathrm{~Gy}$ で54 $\%$, 神戸大学では 44-60Gy で47\% $\%^{6)}$,九州大学, 秋田 大学では $60 \mathrm{~Gy}$ で各々 $54 \%{ }^{7}, 64 \%$, 東京大学では最高 $70 \mathrm{~Gy}$ まで照射し $53 \%$ 9 の成績を得ている．外国では Knegt $ら^{10)}$ は $14 \mathrm{~Gy} て ゙ 52 \%$, Sisson ら ${ }^{11}$ は60Gy 以上 で49\%の成績を報告している。これらの報告は症例の 進展度や放射線量以外の三者併用療法の内容も異な り，また治療後のQOL (quality of life) を考えた場 合一概には比較できない。しかし，成績が悪くなる原 因は局所再発と転移に起因している，局所制御につい ては, 腫汮の初猃時局所進展度が抬大するほど悪くな $\eta^{12)}$ 早期発見が重要になる。近年 CT, MRI が普及し 早期発見に寄与しており，さらに初発症状をよく理解 し，外来にて Telescope を用いた上顎洞の観察が普及 してくれば T1，T2で発見される症例が增えてくると 考えられる ${ }^{13)}$ 。一方，転移に関しては不明な要素が多 くいかなる症例が転移しやすいかを検討した報告は

表 2 局所制御可能であった28例の分化度と治療内容

\begin{tabular}{ccc}
\hline 治 療 & $\begin{array}{c}\text { 高・中分化型 } \\
(\mathrm{n}=17)\end{array}$ & $\begin{array}{c}\text { 低・末分化型 } \\
(\mathrm{n}=11)\end{array}$ \\
\hline 三者併用 & 13 & 9 \\
放治 + 化療 & 2 & 2 \\
放治十手術 & 1 & 0 \\
手 術 & 1 & 0 \\
\hline
\end{tabular}

少な(4)14).

本論文においては，鼻副鼻腔覀性腫場のうち扁平上 皮癌と末分化癌の局所が制御された症例を対象とし て,分化度と転移の関係㧍よび予後について検討した。

\section{II 対象および研究方法}

1984年から1992年の 9 年間に52例の鼻副鼻腔悪性腫 瘍を香川医科大学附属病院で治療した。このうち29例 の扁平上皮癌と 5 例の未分化癌の計34例のう方局所制 御された28例を対象とした。組織の分化度に応じて28 例を高・中分化型群と低・未分化型群の 2 群に分け, 遠隔転移および頚部リンパ節転移との関係を検討し， 各々の群の累積生存率を Kaplan-Meier 法にて求め た.

治療は三者併用療法を原則とした。これは，術前照 射 50Gy，照射中 5-FU $2000 \mathrm{mg}$ 持続動注，照射終了 3 週後拡大デンケル手術よりなる.

\section{III 結 果}

扁平上皮癌㧍よび未分化癌全体の 5 年累積生存率は 18/34（53\%)，局所制御率は28/34（82\%）であった。 6 例が根治不能もしくは局所再発のため $4,11 ， 12$, 21，22，31力月後にそれぞれ原病死した（表 1)．局所 が制御されなかった 6 例のうち，高齢のため放射線照 射しか施行しなかった 1 例と合併症等で根治不能であ

表 3 局所は制御されたが遠隔転移をきたした 7 例

\begin{tabular}{|c|c|c|c|c|c|c|c|c|c|c|}
\hline \multicolumn{3}{|c|}{ 症 例 } & \multirow{2}{*}{$\frac{\text { 原 発 }}{\text { 斾骨洞 }}$} & \multirow{2}{*}{$\frac{T}{X}$} & \multirow{2}{*}{$\frac{\mathrm{N}}{0}$} & \multirow{2}{*}{$\frac{\mathrm{M}}{0}$} & \multirow{2}{*}{$\frac{\text { 分化度 }}{\text { 末 }}$} & \multirow{2}{*}{$\frac{\text { 治 療 }}{\text { 三者併用 }}$} & \multirow{2}{*}{$\frac{\text { 遠隔転移 }}{\text { 肝・脾・脳・骨 }}$} & 転帰 (月) \\
\hline 1. & 48 & 女 & & & & & & & & 死亡 \\
\hline 2. & 61 & 女 & 篩骨洞 & $\mathrm{X}$ & 2 & 0 & 末 & 放治＋化療 & 肺 & 死亡 8 \\
\hline 3. & 67 & 女 & 上顎洞 & 3 & 0 & 0 & 末 & 三者併用 & 肝 & 死亡 19 \\
\hline 4. & 73 & 女 & 上顎洞 & 3 & 0 & 0 & 末 & 三者併用 & 肺 (42Gy) & 生存 89 \\
\hline 5. & 51 & 男 & 上顎洞 & 3 & 0 & 0 & 低 & 三者併用 & 脳 & 死亡 31 \\
\hline 6. & 61 & 男 & 上顎洞 & 3 & 0 & 0 & 低 & 三者併用 & 肝 - 肺 - 骨 & 死亡 3 \\
\hline 7. & 64 & 男 & 上買洞 & 3 & 0 & 0 & 高 & 三者併用 & 肺・皮膚 & 死亡 21 \\
\hline
\end{tabular}


表 4 局所制御可能であった28例の原発部位, 腫湯進展度, 遠隔転移, 分化度の関俰

\begin{tabular}{|c|c|c|c|c|}
\hline 原発部位 & $\begin{array}{c}\text { M0 } \\
(\mathrm{n}=21)\end{array}$ & $\begin{array}{c}M 1 \\
(n=7)\end{array}$ & $\begin{array}{c}\text { 高 - 中分化型 } \\
(\mathrm{n}=17)\end{array}$ & 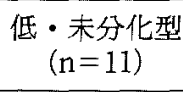 \\
\hline 上顎洞 & 12 & 5 & 9 & 8 \\
\hline $\mathrm{T} 1$ & 0 & 0 & 0 & 0 \\
\hline $\mathrm{T} 2$ & 6 & 0 & 5 & 1 \\
\hline $\mathrm{T} 3$ & 3 & 5 & 3 & 5 \\
\hline $\mathrm{T} 4$ & 3 & 0 & 1 & 2 \\
\hline No & 10 & 5 & 7 & 8 \\
\hline N1 & 1 & 0 & 1 & 0 \\
\hline N2 & 1 & 0 & 1 & 0 \\
\hline Stage I & 0 & 0 & 0 & 0 \\
\hline II & 4 & 0 & 3 & 1 \\
\hline III & 4 & 5 & 4 & 5 \\
\hline IV & 4 & 0 & 2 & 2 \\
\hline 篩骨洞 & 6 & 2 & 5 & 3 \\
\hline 前頭洞 & 1 & 0 & 1 & 0 \\
\hline 鼻 腔 & 2 & 0 & 2 & 0 \\
\hline
\end{tabular}

表 5 分化度と頸部リンパ節転移及び遠隔転移との関係

\begin{tabular}{lccc}
\hline & 高・中分化型 & 低・未分化型 & $\chi^{2}$-test \\
\hline 頸部リンパ節転移群 & 5 & 2 & \\
非頸部リンパ節転移群 & 12 & 9 & $\mathrm{p}=0.82$ \\
\hline 遠隔転移群 & 1 & 6 & $\mathrm{p}=0.014$ \\
非遠隔転移群 & 16 & 5 & \\
\hline
\end{tabular}

つた 2 例を除いた 3 例に三者併用療法を施行した。こ の3例の組織分化度は高・中・低分化型がそれでれ 1 例で, 局所制御と分化度との関係は明らかではなかっ た。

局所制御されていた28例のうち高・中分化型は17例， 低・未分化型は11例で治療内容を表 2 に示した. 28例 のうち，5例に遠隔転移のみ，5例に頸部リンパ節転 移のみ，2 例に遠隔転移と頸部リンパ節転移が認めら れた．７例の遠隔転移症例（表 3）のうち 1 例は手術 を必要とせず局所制御されたが，残り6例は三者併用 療法を施行した。原発部位，腫場進展度 (上顎洞のみ), 遠隔転移との関係を表 4 に示した。分化度と遠隔転移, 澒部リンパ節転移との関係は表 5 に示した。頸部リン パ節転移は分化度と相関しなかったが，遠隔転移は相 関した $(P=0.014)$ ，すなわ方，低・未分化型は高・中 分化型に比し遠隔転移しやすい結果を得な。

局所制御された28例のうち18例が生存し，6例が遠
隔転移のため 1 例がリンパ節転移のため原病死し， 3 例が他因死した. Kaplan-Meier 法で得られた 5 年累 樻生存率は, 頸部りンパ節転移群と非転移群, 遠隔転 移群と非転移群, 高・中分化型群と低・末分化型群を 比較すると，それぞれ57\%と63\%，14\%と78\%(P< 0.01 ), $72 \%$ と $44 \%$ (logrank, $\mathrm{P}=0.061$; generalized Wilcoxon, $\mathrm{P}=0.038$ ) であった（図 1, 2,3）.

\section{IV 考 察}

我々の三者併用療法の成績は局所制御率に関しては $82 \%$ と極めて良好である。し加し，5年生存率は $53 \%$ と低くなり，同じ治療方針のSakai ら5) の報告とほほ 同じ結果を得た。すなわち，この三者併用療法は局所 制御されても生存率を上げるにはいまだ不十分である と考光られる．生存率を上げるためには，局所制御と 転移の予防が必要である，局所制御は腫浧の進展度に 相関し ${ }^{12)}$, 早期発見が最も重要である。また，我々の三 


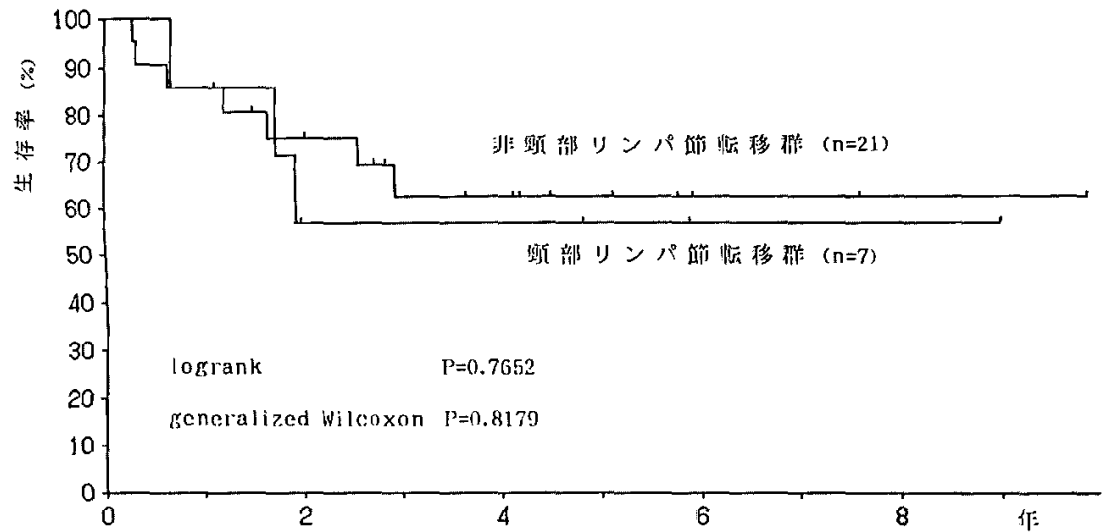

図 1 局所制御された28例の頸部りンパ節転移群と非転移群の累積 生存率 (Kaplan-Meier 法)

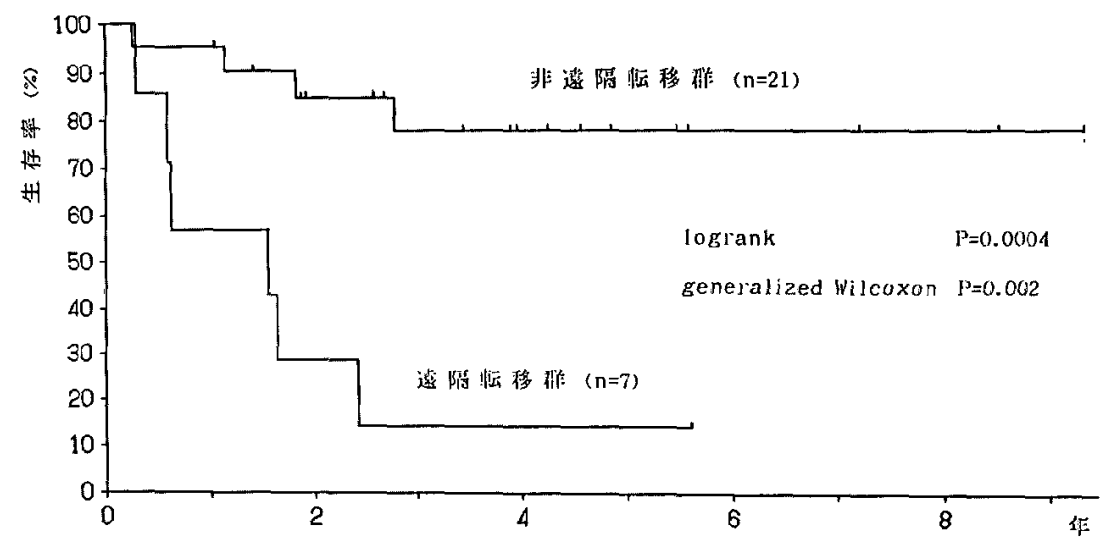

図 2 局所制御された28例の遠隔転移群と非転移群の累積生存率 (Kaplan-Meier 法)

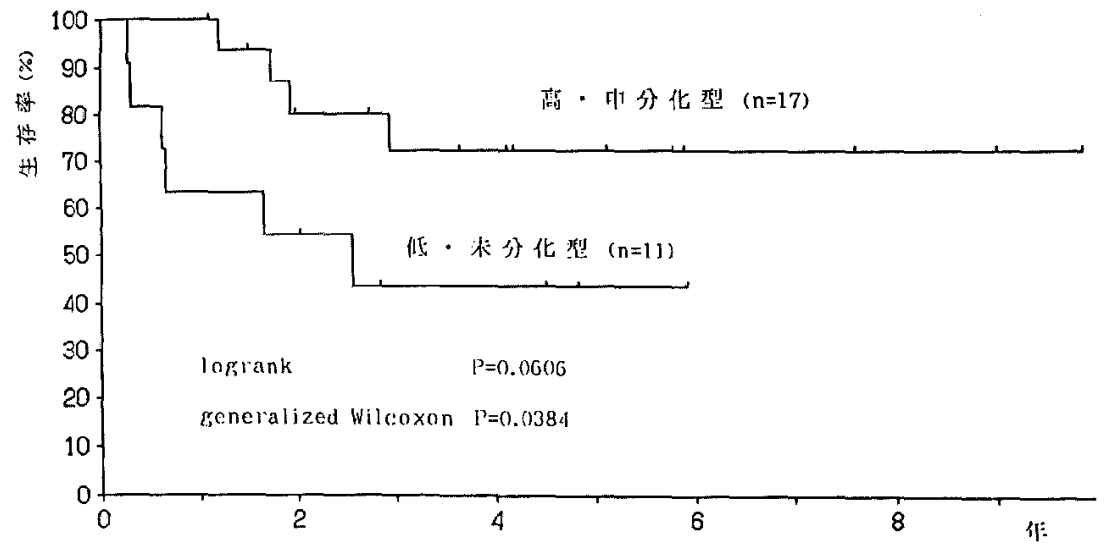

図 3 局所制御された28例の高・中分化型群と低・末分化型群の累 積生存率（Kaplan-Meier 法） 
者併用療法の局所制御率は良好であり，局所制御の成 否と分化度との相関は認められなかったのて，腫湯の 分化度にかかわらず原発部位への治療方針について は，我々の三者併用療法は適当であると考えられる。

転移に関しては, 頸部リンパ節転移群は予後不良と 報告されている(15)16)。本邦においても石井 ${ }^{41}$ は初診時 に頸部リンパ節転移群の予後は不良としているが，局 所再発や遠隔転移を起こした症例も含まれ，局所が制 御された症例では経過中に認められた顓部リンパ節䎐 移は制御可能としている，溝尻6)頸部リンパ節転移 群は予後不良としているが, 頸部リンパ節転移死はな く局所再発や遠隔転移死によるものであり，局所再発 と頸部りンパ節転移との相関を報告している。我々の 症例においては，局所が制御され，遠隔転移のない顠 部リンパ節転移症例は4/5（80\%）制御可能であった。 また, 頸部りンパ節転移の有無と腫場の分化度は相関 せず，5年照積生存率も頸部りンバ節転移群と非転移 群はそれぞれ57\%と63\%であり，予後に関係しなかっ た、したがって，初診時に頸部リンパ節を触知しない 症例には，予防的な治療は必要がなく，治療中もしく は経過観察中に触知した段階で頸部郭清術を施行する のが適当と考えられる。

遠隔転移を起こした症例のうち，肺転移例の1例が 放射線照射で制御されたが6/7 (86\%) 腫富死した。 5 年累積生存率では局所制御された 28 例のうち，遠隔転 移群14\%であるのに対し，非転移群では78\%であった $(\mathrm{P}=0.002)$. 酒井 ${ }^{177}$ は三者併用療法中に積極的に描爬 による滅量手術を施行した症例は局所制御率はよく病 るが遠隔転移をきたしやすいと報告している。これは 分化度に関係したもので住なく掻爬という機械的刺激 が誘因と考察している. 本田ら ${ }^{18\}}$ 部分切除術による 減量後，抗癌剂動注と照射を主体とした治療法で上顎 洞癌再発・転移例の11/16（69\%）が低分化型であり， 低分化型の約 $50 \%$ が再発転移したと報告している。 た，今野ら ${ }^{14)}$ や石井 ${ }^{4}$ は未分化癌，低份化型扁平上皮 癌では遠隔転移を起こしゃすいと報告しているが，い ずれも検定が行われていない，我々の局所制御例での 検討では，迠隔転移は低・未分化型に有意 $(\mathrm{P}=0.014)$ に多く、これが 5 年生存率が高・中分化型 $73 \%$, 低・ 末分化型 $44 \%$ 差となっていると考光られる.

したがって，鼻副鼻腔癌の治療成績を向上させるた めには，早期発見敒努めることはもちろんであるが， 低・未分化型の遠隔転移を予防しなければならない。 遠隔転移の予防としては, 化学療法 (Neo-adjuvant,
Adjuvant）と免疫療法が考えられる。このうち化学療 法に関しては犬山 ${ }^{199}$ は上䫑洞癌に Neo-adjuvant 化 学療法を行い，上頧全摘率を減少させたが 5 年生存率 は55\%と満足にいたる成績とならず著者らの報告とほ 浔同じ成績を報告している. Adjuvant 化学療法につ いては，鼻副鼻腔癌の遠隔転移をどの程度予防できる かを检討した報告はない。他領域に抒いては Niiranen $ら^{20)}$ は非小細胞肺癌に扔いて, 手術単独群より Adjuvant 化学療法併用群の成績が有意に優れていると 報告し，乳癌においても同様に Adjuvant 化学療法の 有用性が報告されている21!

著者らはこの研究の結果加低・未分化型鼻副鼻腔 癌に対し，我々の三者併用療法は良好な局所制御が可 能であり，今後 Adjuvant 化学療法を行うことにより 遠隔転移を予防するのが適当ではないかと考えるよう になった. Adjuvant 化学療法の内容に関しては, 犬山 ら ${ }^{22)}$ は頭頸部癌の遠隔転移には CDDP を主体とした ものが有用であるとしているが，具体的な内容につい ては今後に残された課題である.

\section{$\mathrm{V}$ 結 語}

鼻副鼻腔癌34例の治療結果を検討した，

1. 5 年累積生存率は $53 \%$, 局所制御率は $82 \%$ であ つた.

2. 局所制御と分化度との関係は明らかではなかっ t.

3. 局所制御された28症例では, 頸部リンパ節転移 と分化度との関係は認めなかった。 $(\mathrm{P}=0.82)$

4. 局所制御された28症例では, 遠隔転移は有意 $(\mathrm{P}=0.014)$ に低分化型扁平上皮癌々末分化癌に起こ りやす汃た。

\section{参考文献}

1）高橋廣臣，岡本牧人，八尾和雄，稻木勝英：上顥癌の 治㙩成績一とくに放射線照射との関連について一，耳 鼻臨 補 $42: 168-173 ， 1991$ 。

2) 三橋重信：レーザー手術を含んだ集学治療。耳鼻臨 78: 696-698, 1985

3）森田守，宮田守，五十嵐丈人、藤本泰幸，井上 耕他：上顎癌の併用療法一ことに T4 症例の治療法 について。聑鼻 92：169-175，1989

4) 石井政則：上顎洞癌134例の臨床的検討.耳展補 4: 407-423, 1984

5) Sakai S, Hohki A, Fuchihata $H$ et al: Multidisciplinary treatment of maxillary sinus carcinoma. 
Cancer $52: 1360-1364,1983$.

6) 渾尻源太郎: 上罰癌最近 7 年間の治療成績一第 2 報 $\mathrm{T} 3$ 症例の治療方針，䁰部りンパ節転移について一。 耳鼻臨 80：427-434，1987。

7）小宮山荘太郎：上䂓癌のFAR 療法.耳鼻臨 78 : 685-687, 1985.

8) Konno $A$, Togawa $K$, Inoue $S$ : Analysis of the results of our combined therapy for maxillary can. cer. Acta Otolaryngologica Supple 372: 1-16, 1980.

9) Sakata K, Aoki $Y$, Karasawa $K$ et al: Analysis of the results of combined therapy for maxillary car. cinoma. Cancer 71:2715-2722, 1993.

10) Knegt PP, De Jong PC, Van Andel JG et al: Carcinoma of the paranasal sinuses. Result of a prospective pilot study. Cancer 56: 57-62, 1985.

11) Sisson GA, Toriumi DM, Atiyah RA: Paranasal sinus malignancy: a compresive update. Laryn. goscope $99: 143-150,1989$.

12) Kondo $M$, Inuyama $Y$, Ando $Y$ et al: Patterns of relapse of squamous cell carcinoma of the maxillary sinus. Cancer 53:2206-2210, 1984.

13) Miyaguchi M, Sakai $S$, Mori $N$ et al : Symptoms in patients with maxillary sinus carcinoma. J Laryn. gol Otolog 104: 557-559, 1990.

14）今野昭義, 井上周一：上疑癌治療上の問題点.耳鼻 $29: 318-320,1983$.

15) Lindeman P, Eklund U, Petruson B : Survival after surgical treatment in maxillary neoplasms of epithelial origin. J Laryngol Otolog 101 : 564-568, 1987.

16) Giri SPG, Reddy EK, Germer LS et al : Management of advanced squamous cell carcinoma of the maxillary sinus. Cancer 69:657-661, 1992.

17）酒井俊一：上颚洞癌の遠隔転移発生頻度.耳鼻 29 ： 329-331, 1983.

18）本田哲朗, 大山和一郎, 渡嘉敷輝彦, 広川剛夫, 高田 研太 他：上頻洞癌再発・転移例の検討、耳鼻臨 76 : 2495-2500, 1983.

19）犬山征大：頭頸部癌に対する neoadjuvant chemotherapy. 耳鼻臨 $82: 1043-1050,1989$.

20) Niiranen $A$, Niitamo-Korhonen $S$, Kouri $M$ et al: Adjuvant chemotherapy after radical surgery for non-small cell lung cancer: A rondomized study. J Clin Oncol 10 : 1927-1932, 1992.

21) Early Breast Cancer Trials' Collaborative Group: Effects of adjuvant tamoxifen and of cytotoxic therapy on mortality in early breast cancer. $\mathrm{N}$ Engl J Med 319 : 1681-1692, 1988.

22）犬山征夫, 古田康, 福田 諭, 佐藤信清, 川崎和子 他：頭頸部癌の遠隔転移に対する治療成績。頭頸腫煌 17: 42-46, 1991.

（1994年4月 1 日受稿 1994年 7月21日受理）

別刷請求先 $テ 761-07$ 香川県木田郡三木町

大字池戸1750-1

香川医科大学耳鼻咽知科学教室 宮口 衛 